\title{
Serum and Glucocorticoid Inducible Kinase 1-Sensitive Survival, Proliferation and Migration of Rhabdomyosarcoma Cells
}

\author{
Evi Schmid ${ }^{a}$ Matias Julian Stagno ${ }^{a}$ Jing Yan ${ }^{c}$ Sabine Schleicher ${ }^{b}$ Willi Yuc \\ Sabina Honischc Florian Lang ${ }^{d}$ Jörg Fuchs ${ }^{a}$ Guido Seitz ${ }^{a, e}$
}

\begin{abstract}
aDepartment of Pediatric Surgery \& Pediatric Urology, ${ }^{b}$ Department of Haematology and Oncology, Children's Hospital, 'Department of Cardiology and Vascular Medicine, dDepartment of Physiology I, Eberhard-Karls-University Tuebingen, ${ }^{e}$ Department of Pediatric Surgery, University Hospital Marburg, Germany
\end{abstract}

\section{Key Words}

SGK1 $・$ Rhabdomyosarcoma $•$ Migration $•$ Cell proliferation $\bullet$ Clonal cell growth

\begin{abstract}
Background/Aims: Rhabdomyosarcoma, the most common pediatric soft tissue sarcoma, may show an intrinsic refractoriness to standard chemotherapy in advanced tumor stages, which is associated with poor prognosis. Cellular mechanisms conferring tumor cell survival and therapy resistance in many tumor types include the serum \& glucocorticoid inducible kinase (SGK) 1 pathway, a kinase expressed ubiquitously with particularly strong expression in skeletal muscle and some tumor types. The present study explored whether SGK1 is expressed in rhabdomyosarcoma and, if so, whether this kinase impacts on tumor cell survival, proliferation and migration. Multiple in vitro techniques were used to study the role of SGK1 in rhabdomyosarcoma. Methods: The

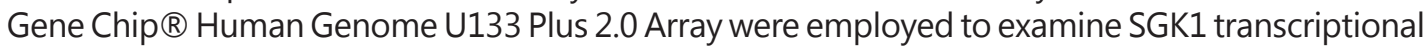
activity in healthy muscle and rhabdomyosarcoma tissue. SGK1 transcript levels were quantified in rhabdomyosarcoma cell lines RD (embryonal subtype) and RH30 (alveolar subtype) by RTPCR, cell viability was measured using MTT assays. Clonal cell growth was assessed via colony forming assays and migration experiments were performed in a transwell system. Results: SGK1 is expressed in embryonal and alveolar rhabdomyosarcoma tissue samples and in RD and RH30 rhabdomyosarcoma cell lines. Administration of EMD638683 - an inhibitor specific for SGK1 decreased viability of RD and RH30 cells, enhanced the effects of the cytotoxic drug doxorubicin leading to reduced migration and decreased cell proliferation. Conclusions: SGK1 is expressed in rhabdomyosarcoma cells where it contributes to survival, therapy resistance, cell proliferation and migration. Thus, SGK1 inhibitors may be considered a therapeutic option for the treatment of therapy-resistant rhabdomyosarcoma.

E. Schmid and M.J. Stagno authors contributed equally and thus share first authorship. 


\section{Cellular Physiology Cell Physiol Biochem 2017;43:1301-1308 and Biochemistry \begin{tabular}{c|c} 
DOI: 10.1159/000481842 \\
Published online: October 09, 2017
\end{tabular}}

Schmid et al.: SGK1 and the Survival of Rhabdomyosarcoma Cells

\section{Introduction}

Rhabdomyosarcoma is the most prevalent soft tissue sarcoma in children and adolescents, accounting for $5 \%$ of all pediatric tumors [1]. The two main histological subtypes of RMS are embryonal (RME) and alveolar (RMA) RMS. RMA is driven typically by the fusion proteins PAX3-FKHR or PAX7-FKHR [2]. Seventy percent of all RMS in children are diagnosed less than 10 years of age, which are mostly RME. In contrast, RMA occur mostly in adolescent and young adults [3]. Prognosis is related to the localization of the primary tumor, its histological subtype, tumor size at diagnosis, the stage of disease and the age of the patient at time point of diagnosis $[4,5]$. Patients with advanced stage disease, metastatic disease and local tumor recurrence have a poor prognosis. Survival rates have not improved over the past 20 years $[6,7]$. Therefore novel therapeutic strategies are urgently needed for these patients.

Mechanisms conferring tumor cell survival and therapy resistance include the serum \& glucocorticoid inducible kinase SGK1, initially identified in mammary tumor cells [8-14], yet then found as being ubiquitously expressed with strong emphasis in skeletal muscle [15] and highly upregulated in different tumors such as colonic cancer [16], hepatocellular carcinoma $[17,18]$, breast cancer [18-20], prostate cancer [21, 22], glioblastoma [23-25], non-small cell lung cancer [26], meningiomas [27], and medulloblastoma [28]. Several studies demonstrate a pivotal role for SGK1 in cell survival, cell proliferation and migration of tumor cells [16, 29].

In addition, SGK1 was shown to be essential for IL2-dependent protection of doxorubicin induced apoptosis in kidney cancer cells, suggesting a SGK1-mediated chemotherapy resistance of tumor cells [30]. Accordingly, SGK1 knock-out mice were more sensitive to kidney failure under doxorubicin treatment $[12,31]$ while inhibition of SGK1 via RNA silencing increased the toxicity of chemotherapeutic drugs in cancer cells [12, 31]. The highly selective SGK1 inhibitor EMD638683 proved to be effective in vitro and was the first SGK1 inhibitor also effective in vivo [32].

The present study explored whether EMD638683 alone or in combination with the cytotoxic drug doxorubicin could decrease cell viability, proliferation and migration of rhabdomyosarcoma cells in vitro.

\section{Material and Methods}

Cell lines and culture conditions

The RME cell line RD (ATCC, Manassas, VA, USA) and the RMA cell line RH30 (DSMZ, Braunschweig, Germany) were routinely cultured in DMEM medium (Biochrom, Berlin, Germany) supplemented with $10 \%$ fetal bovine serum (Biochrom, Berlin, Germany), 1\% penicillin/streptomycin (Biochrom, Berlin, Germany) and 1\% l-glutamine (Biochrom, Berlin, Germany) in a humidified atmosphere containing $5 \% \mathrm{CO}_{2}$ at $37 \mathrm{C}$. Cell identity was proven by SLR analysis of the DNA profile using PowerPlex 16 (Promega, Mannheim, Germany). All cells were tested to be mycoplasma negative (Lonza, Cologne, Germany). The RMS cell lines were treated with the SGK1 inhibitor EMD638683 (APExBIO, Houston, Texas, USA, IC50 $3 \mu \mathrm{M}$ ) in the absence and presence of doxorubicin for the indicated periods and with the indicated concentrations. The concentration of EMD638683 has previously been shown to be effective [20, 33, 34].

\section{RNA extraction and oligonucleotide microarrays}

RMS tumor specimen and muscle tissue were immediately fixed in liquid nitrogen and stored at $-80^{\circ} \mathrm{C}$ for further gene chip analysis. Total RNA extraction was carried out using the RNeasy Mini Kit (Qiagen, Hilden, Germany). The quality of the tumor RNA was monitored by an Agilent 2100 Bioanalyzer using the RNA6000 Nano LabChip Kit (Agilent Technologies, Boeblingen, Germany) as specified by the manufacturer. Samples with RIN>8 were considered for gene chip analysis. Affymetrix high-density oligonucleotide microarrays (GeneChip® Human Genome U133 Plus 2.0 Array, Affymetrix, Santa Clara, CA, USA) were used for gene expression analysis. Hybridization experiments and evaluation was done by the Microarray Facility Tuebingen, as originally described by Armeanu-Ebinger [35, 36]. The patient characteristics have been published by Armeanu-Ebinger et. al. [35] and were approved by the local ethics committees. 


\section{Cellular Physiology Cell Physiol Biochem 2017;43:1301-1308 and Biochemistry \begin{tabular}{c|l} 
DOI: 10.1159/000481842 \\
Published ontne: October 09, 2017
\end{tabular}}

Schmid et al.: SGK1 and the Survival of Rhabdomyosarcoma Cells

Real time PCR

Determination of SGK1 transcript levels was performed by RT-PCR. Total RNA was extracted from RD and RH30 cells using RNeasy Mini kit (Qiagen, Hilden, Germany) according to the manufacturer's instructions. Reverse transcription of total RNA was performed using High capacity cDNA Reverse Transcription Kit (Applied Biosystems, Waltham, Massachusetts, USA). Polymerase chain reaction (PCR) amplification of the respective genes were set up in a total volume of $20 \mu \mathrm{l}$ using $40 \mathrm{ng}$ of cDNA, $500 \mathrm{nM}$ forward an reverse primer and 2x GoTaq ${ }^{\circledR}$ qPCR Master Mix (Promega Corporation, Madison, WI, USA) according to the manufacturer's protocol. Cycling conditions were as follows: initial denaturation at $95^{\circ} \mathrm{C}$ for 5 minutes, followed by 40 cycles of $58^{\circ} \mathrm{C}$ for 30 seconds and $72^{\circ} \mathrm{C}$ for 20 seconds. For the amplification the following primers were used (5’-3`orientaion):

SGK1 fw: GCTCCGACATAATATGCTTCTCC

SGK1 rev: GGCACTTCTAGCAAGACACAAGG;

TBP fw: GCC CGA AAC GCC GAA TAT

TBP rev: CCG TGG TTC GTG GCT CTC

Specificity of PCR product was confirmed by melting curve analysis. Real-time PCRs were performed on a CFX96 Real-Time System (Bio-Rad). All experiments were done in duplicates. Amplification of the house-keeping gene TBP (TATA binding protein) was performed to standardize the amount of sample RNA. Relative quantification of gene expression was achieved using the $\Delta \mathrm{ct}$ method.

Cell viability assay

$8 \times 10^{3}$ cells were seeded per well in 96-well plates. After overnight adherence of the cells and 72 hour treatment with EMD638683 (APExBIO, Houston, Texas, USA) in combination with and without doxorubicin cell viability was determined by means of a colorimetric MTT-assay measuring the reduction of tetrazolium salts to formazan derivatives by functional mitochondria. Lysis buffer (DMSO, SDS, acid) was added to solubilize the blue MTT-formazan product. The assays were performed in triplicates as previously described [37]. Absorbance was measured at 570nm.

\section{Clonogenic assay}

Cells were plated in 6-well plates at 500 cells per well in $2 \mathrm{ml}$ of media. After attachment cells were treated with or without EMD638683 for 72 hours in a humidified atmosphere of $37^{\circ} \mathrm{C}$ and $5 \% \mathrm{CO}$. After 72 hours cells were washed twice with PBS and fresh medium was added. The colonies grew 7-10 days, before being fixed with $80 \%$ methanol and stained with $0.2 \%$ crystal violet. Number of colonies ( $>50$ cells) were counted microscopically [38].

In vitro migration assay

For transwell migration assays, $5 \times 10^{4}$ cells were placed in the top chamber with a non-coated membrane (24-well insert; $8 \mu \mathrm{m}$ pore size, BD Biosciences) in serum-free medium whereas the lower chamber of the transwell system contained medium with $10 \%$ fetal bovine serum as chemoattractant. The cells were incubated during the experiment with EMD638683 for $24 \mathrm{~h}$ (RH30) or $48 \mathrm{~h}$ (RDs) in a humidified atmosphere of $37^{\circ} \mathrm{C}$ and $5 \% \mathrm{CO}_{2}$. Cells that did not migrate through the pores of the transwell membrane were removed by a cotton swab and washed with PBS. The transwells were moved to $4 \%$ paraformaldehyde (PFA) and incubated for $15 \mathrm{~min}$ at room temperature. Membranes were removed by scalpel, placed on slides and stained with Giemsa. The migrated cells bound on the lower surface to the membrane were then counted at 3 different regions using Axio Vision Release 4.8 software (Carl Zeiss Vision, Oberkochen, Germany).

\section{Statistics}

Data are provided as means $\pm \mathrm{SEM}, n$ represents the number of independent experiments. All data were tested for significance using unpaired Student $t$-test or ANOVA (Bonferroni test, Dunnett test) using GraphPad Prism version 4.0 (GraphPad Software, Inc.). Only results with $\mathrm{p}<0.05$ were considered statistically significant. 


\section{Results}

The present study addressed expression and functional significance of SGK1 in rhabdomyosarcoma cells. SGK1 transcription levels were determined in muscle tissue, alveolar (RMA) and embryonal (RME) rhabdomyosarcoma tumors. As illustrated in Fig. 1A, the SGK1 mRNA expression was significantly higher in alveolar rhabdomyosarcoma tissue

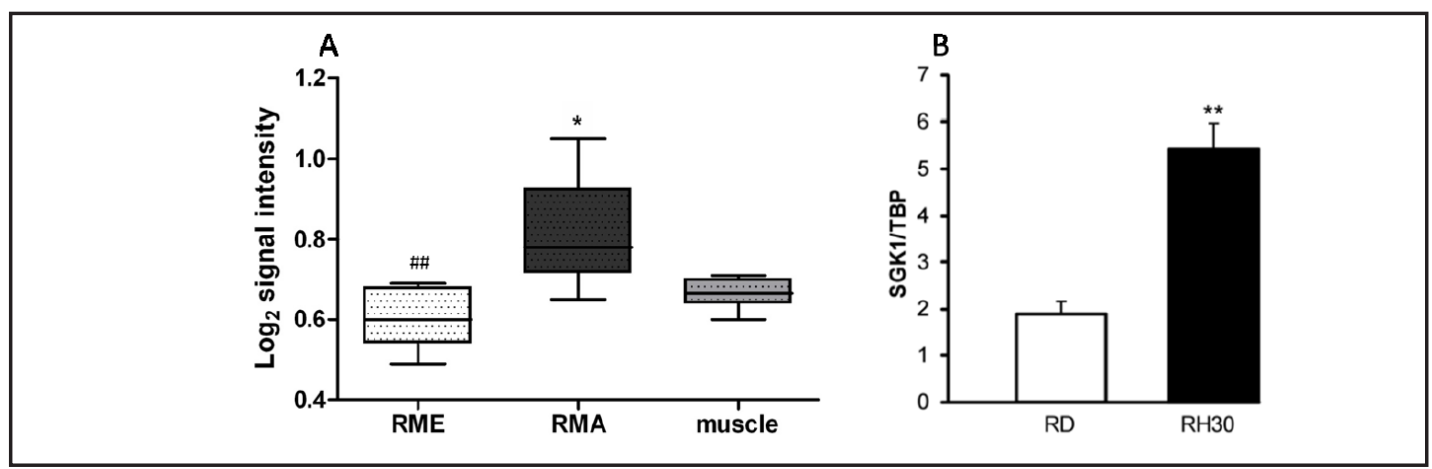

Fig. 1. SGK1 transcript levels in muscle tissue, rhabdomyosarcoma tumor tissue and cell lines. A. Individual Gene Chip® Human Genome U133 Plus 2.0 Array values and arithmetic means \pm SEM of SGK1 transcript levels in muscle tissue (muscle, $n=8$ ), alveolar (RMA, $n=5$ ) and embryonic (RME, $n=6$ ) rhabdomyosarcoma tissue. ${ }^{*}(p<0.05)$ indicates statistically significant difference from muscle, $\# \#(p<0.01)$ indicates statistically significant difference from RMA. B. Arithmetic means \pm SEM $(n=7)$ of SGK1 relative to TBP transcript levels in RD and RH30 cells. ** $(\mathrm{p}<0.01)$ indicates statistical significance
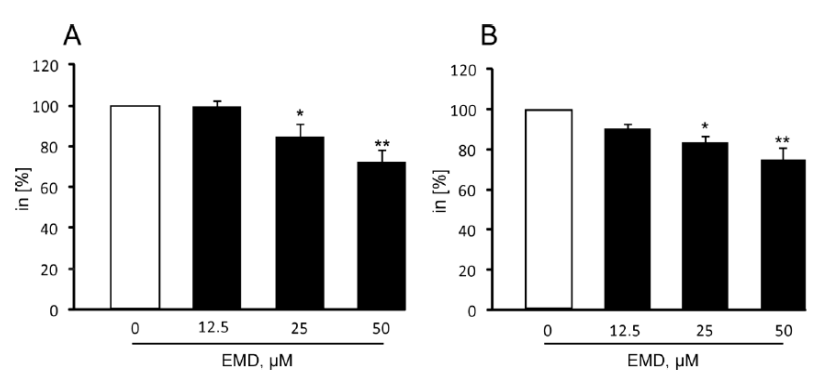

Fig. 2. Effect of the SGK1 inhibitor EMD638683 on the viability of RD and RH30 rhabdomyosarcoma cells. A,B. Arithmetic means \pm SEM ( $n=4)$ of the relative numbers of viable RD (A) and RH30 (B) cells following a 72 hours incubation in the presence of 12.5, 25 and $50 \mu$ M SGK1 inhibitor EMD638683 (black bars) relative to the absence of EMD638683 (white bars). * $(\mathrm{p}<0.05)$; ${ }^{* *}(\mathrm{p}<0.01)$ indicates statistical significance

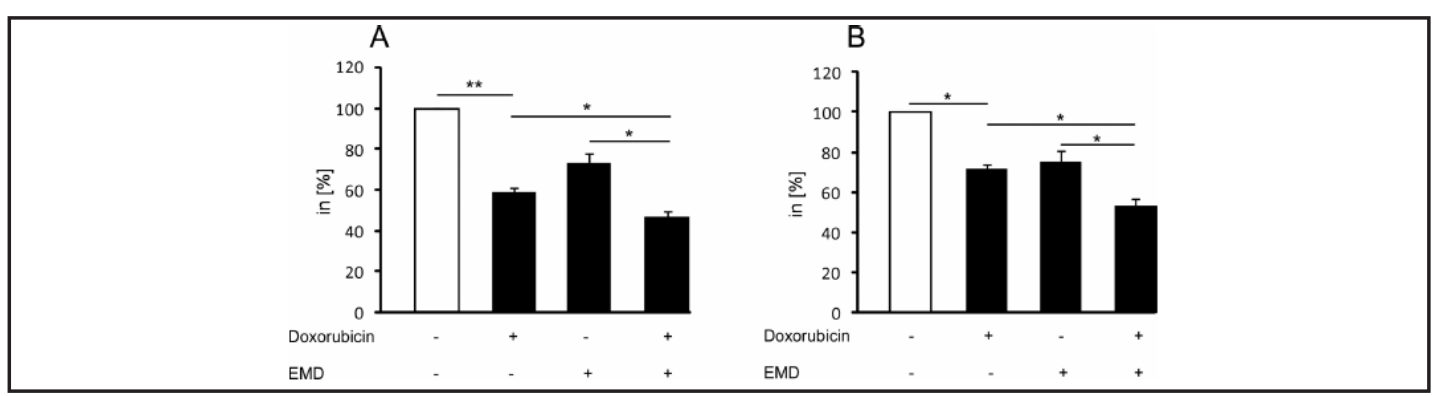

Fig. 3. Effect of the SGK1 inhibitor EMD638683 on doxorubicin sensitivity of RD and RH30 rhabdomyosarcoma cells. A,B. Arithmetic means \pm SEM $(n=4)$ of the relative numbers of viable RD (A) and RH30 (B) cells following a 72 hours incubation in the absence (white bars) and presence (black bars) of $50 \mu \mathrm{M}$ SGK1 inhibitor EMD638683 with and without $0.025 \mathrm{mg} / \mathrm{ml}$ doxorubicin. ${ }^{*}(\mathrm{p}<0.05),{ }^{* *}(\mathrm{p}<0.01)$ indicates statistical significance

\section{KARGER}




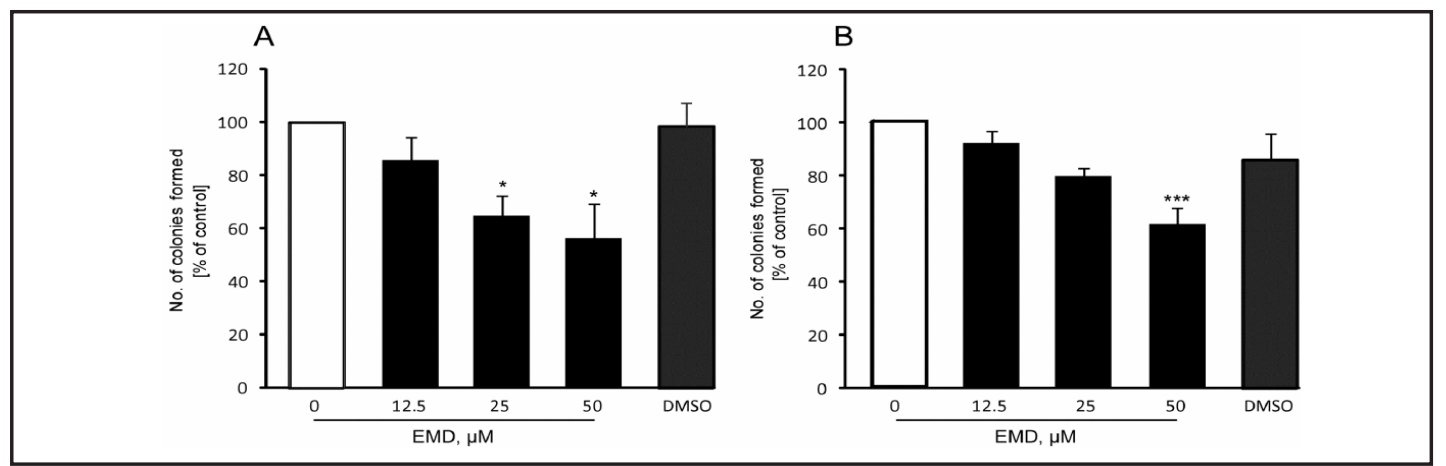

Fig. 4. Effect of the SGK1 inhibitor EMD638683 on cell proliferation in a clonogenic assay. A,B. Arithmetic means \pm SEM ( $n=5)$ of the percentage of evolving clones of RD (A) and RH30 (B) cells following a 72 hours incubation in the presence of 12.5, 25 and $50 \mu \mathrm{M}$ SGK1 inhibitor EMD638683 (black bars) relative to the clones in the absence of EMD638683 (white bars). * $(\mathrm{p}<0.05) ;{ }^{* *}(\mathrm{p}<0.001)$ indicates statistical significance.

Fig. 5. Effect of the SGK1 inhibitor EMD638683 on the migration of rhabdomyosarcoma cells. A,B. Arithmetic means \pm SEM $(n=6)$ of the percentage migrated RD (A) and RH30 (B) cells in the absence (white bars) and presence (black bars) of SGK1 inhibitor EMD638683 $(50 \mu \mathrm{M}, 24 \mathrm{~h}) .{ }^{*}(\mathrm{p}<0.05)$ indicates statistical significance.

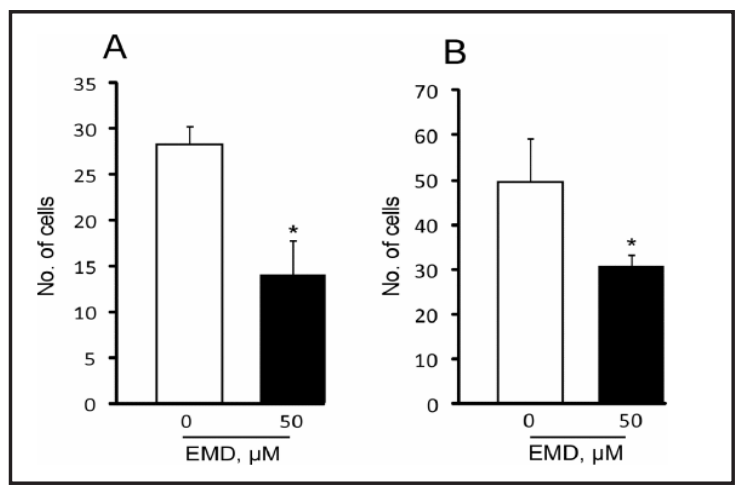

than in muscle tissue. The abundance of SGK1 transcript levels was significantly lower in embryonal than in alveolar rhabdomyosarcoma. SGK1 transcripts were further detected in the RD and RH30 rhabdomyosarcoma cell lines as shown in Fig. 1B - with significantly higher amounts of SGK1 transcripts present in RH30 compared to RD cells.

The specific and selective SGK1 inhibitor EMD638683, which is highly effective in vivo [30], was used to define the functional significance of SGK1 on survival, proliferation and migration of rhabdomyosarcoma cells. As illustrated in Fig. 2, EMD638683 treatment resulted in a statistically significant decline of cell viability in both RD and RH30 cells. A further series of experiments explored whether SGK1 modifies the negative effect of the cytotoxic drug doxorubicin with respect to cell viability. As shown in Fig. 3, doxorubicin treatment clearly decreased the viability of RD and RH30 cells, an effect that was significantly enhanced by the simultaneous administration of EMD638683.

The impact of SGK1 on clonal growth was quantified by colony forming assays. As shown in Fig. 4 - the relative numbers of evolving clones was significantly decreased in the presence of SGK1 inhibitor EMD638683 in RD and RH30 cells. A final series of experiments explored whether pharmacological SGK1 inhibition affected RD or RH30 cell migration. As shown in Fig. 5, the percentage of RD and RH30 cells that migrated through a transwell chamber was significantly decreased in the presence of EMD638683.

\section{Discussion}

In the present study we showed for the first time, that serum \& glucocorticoid inducible kinase SGK1 is expressed in RMS, including both embryonal and alveolar rhabdomyosarcoma 
tumor tissue samples and rhabdomyosarcoma cell lines RD and RH30. Interestingly, the more aggressive alveolar rhabdomyosarcoma express higher levels of SGK1 than the embryonal rhabdomyosarcoma. This observation is in full agreement with former observations that SGK1 interacts with several proteins like glycogen synthase kinase (GSK) 3 [39], N-myc downstream regulated 1 gene (NDRG1) $[40,41]$ and transcription factors FKRHL1 $[42,43]$ and NFKB [44] which in turn support cell survival, cell growth and inhibit apoptosis.

Importantly, pharmacological inhibition of SGK1 with the specific inhibitor EMD638683 was able to significantly decrease RMS cell's viability, proliferation and capacity to migrate. Moreover, the sensitivity of RMS cell lines to the cytotoxic drug doxorubicin was enhanced, which is in complete accordance with reports that show SGK1 supporting cell proliferation, stimulating their migration and counteracting apoptosis in diverse tumor cell types [16, 29], including colorectal carcinoma [11-13, 16, 45], hepatocellular carcinoma [17, 18], breast cancer [18-20], prostate cancer [21, 22], glioblastoma [23-25], non-small cell lung cancer [26], meningiomas [27] and medulloblastoma [28].

SGK1 kinase is involved in the regulation of factors fundamental for activation, proliferation and cell survival including the up-regulation, abundance and activity of ionchannels and carriers as well as $\mathrm{Na}^{+} / \mathrm{K}^{+}$-ATPases. SGK1 also modulates the activity of enzymes belonging to important pathways such as glycogen-synthase-kinase-3 (GSK3), ubiquitin-ligase Nedd4-2, as well as the pivotal transcription factors NFKB and $\beta$-catenin [16]. SGK1 may also support and facilitate tumor growth by the activation of $\mathrm{K}^{+}$and $\mathrm{Ca}^{2+}$ channels, modulation of $\mathrm{Na}^{+} / \mathrm{H}^{+}$exchanger and amino acid and glucose transporters; likewise via nuclear factor $\mathrm{NFKB}$ and $\beta$-catenin signaling while downregulating the transcription factors Foxo3a/FKHRL1 and p53 central players in cell survival [16]; SGK1 finally affects RAN/RANBP1/ RANGAP1 via SP1, thus playing a critical role in pre-miRNA nuclear export and epigenomic regulation [46].

Although this study did not focus on the pathways involved in the cyto reductive behavior of SGK1 towards RMS the observations of our present study indicates that inhibition of SGK1 may be a therapeutic option in rhabdomyosarcoma. It is noteworthy that the inhibitor is well tolerated in vivo [32], and that the phenotype of gene targeted mice lacking functional SGK1 is mild [31]. Thus SGK1 either alone or combined with doxorubicin presents as a promising strategy to prevent or overcome intrinsic mechanisms of resistance of RMS cells to chemoand radiotherapy.

\section{Acknowledgements}

The authors acknowledge the technical support by Bettina Kirchner and Melanie Hauth and the IT support by Olaf Kupka. This study was supported by the Deutsche Forschungsgemeinschaft (GRK 1302, SFB 773) and the Open Access Publishing Fund of Tuebingen University.

\section{Disclosure}

The authors of this manuscript declare that they have no conflicts of interests

\section{References}

1 Yang L, Takimoto T, Fujimoto J: Prognostic model for predicting overall survival in children and adolescents with rhabdomyosarcoma. BMC Cancer 2014;14:654.

2 Marshall AD, Grosveld GC: Alveolar rhabdomyosarcoma - The molecular drivers of PAX3/7-FOXO1-induced tumorigenesis. Skelet Muscle 2012;2:25.

3 Sun X, Guo W, Shen JK, Mankin HJ, Hornicek FJ, Duan Z: Rhabdomyosarcoma: Advances in Molecular and Cellular Biology. Sarcoma 2015;2015:232010.

- 4 Dantonello TM, Int-Veen C, Harms D, Leuschner I, Schmidt BF, Herbst M, Juergens H, Scheel-Walter HG, Bielack SS, Klingebiel T, Dickerhoff R, Kirsch S, Brecht I, Schmelzle R, Greulich M, Gadner H, Greiner J, 


\section{Cellular Physiology Cell Physiol Biochem 2017;43:1301-1308 and Biochemistry \begin{tabular}{c|c|c|c|} 
DOI: 10.1159/000481842 & P 2017 The Author(s). Published by S. Karger AG, Basel \\
Published & www.karger.com/cpb
\end{tabular}}

Schmid et al.: SGK1 and the Survival of Rhabdomyosarcoma Cells

Marky I, Treuner J, Koscielniak E: Cooperative trial CWS-91 for localized soft tissue sarcoma in children, adolescents, and young adults. J Clin Oncol 2009;27:1446-1455.

Hayes-Jordan A, Andrassy R: Rhabdomyosarcoma in children. Curr Opin Pediatr 2009;21:373-378.

Koscielniak E, Morgan M, Treuner J: Soft tissue sarcoma in children: prognosis and management. Paediatr Drugs 2002;4:21-28.

Roberts SS, Chou AJ, Cheung NK: Immunotherapy of Childhood Sarcomas. Front Oncol 2015;5:181.

D’Antona L, Amato R, Talarico C, Ortuso F, Menniti M, Dattilo V, Iuliano R, Gigliotti F, Artese A, Costa G,

Schenone S, Musumeci F, Abbruzzese C, Botta L, Trapasso F, Alcaro S, Paggi MG, Perrotti N: SI113, a specific inhibitor of the Sgk1 kinase activity that counteracts cancer cell proliferation. Cell Physiol Biochem 2015;35:2006-2018.

-9 Salis O, Bedir A, Gulten S, Okuyucu A, Kulcu C, Alacam H: Cytotoxic effect of fluvastatin on MCF-7 cells possibly through a reduction of the mRNA expression levels of SGK1 and CAV1. Cancer Biother Radiopharm 2014;29:368-375.

10 Amato R, D’Antona L, Porciatti G, Agosti V, Menniti M, Rinaldo C, Costa N, Bellacchio E, Mattarocci S, Fuiano G, Soddu S, Paggi MG, Lang F, Perrotti N: Sgk1 activates MDM2-dependent p53 degradation and affects cell proliferation, survival, and differentiation. J Mol Med (Berl) 2009;87:1221-1239.

11 Towhid ST, Liu GL, Ackermann TF, Beier N, Scholz W, Fuchss T, Toulany M, Rodemann HP, Lang F: Inhibition of colonic tumor growth by the selective SGK inhibitor EMD638683. Cell Physiol Biochem 2013;32:838848.

12 Nasir O, Wang K, Foller M, Gu S, Bhandaru M, Ackermann TF, Boini KM, Mack A, Klingel K, Amato R, Perrotti N, Kuhl D, Behrens J, Stournaras C, Lang F: Relative resistance of SGK1 knockout mice against chemical carcinogenesis. IUBMB Life 2009;61:768-776.

13 Qin J, Chen JX, Zhu Z, Teng JA: Genistein inhibits human colorectal cancer growth and suppresses miR-95, Akt and SGK1. Cell Physiol Biochem 2015;35:2069-2077.

14 Lang F, Stournaras C: Serum and glucocorticoid inducible kinase, metabolic syndrome, inflammation, and tumor growth. Hormones (Athens) 2013;12:160-171.

15 Waldegger S, Barth P, Raber G, Lang F: Cloning and characterization of a putative human serine/threonine protein kinase transcriptionally modified during anisotonic and isotonic alterations of cell volume. Proc Natl Acad Sci U S A 1997;94:4440-4445.

16 Lang F, Perrotti N, Stournaras C: Colorectal carcinoma cells--regulation of survival and growth by SGK1. Int J Biochem Cell Biol 2010;42:1571-1575.

17 Talarico C, D’Antona L, Scumaci D, Barone A, Gigliotti F, Fiumara CV, Dattilo V, Gallo E, Visca P, Ortuso F, Abbruzzese C, Botta L, Schenone S, Cuda G, Alcaro S, Bianco C, Lavia P, Paggi MG, Perrotti N, Amato R: Preclinical model in HCC: the SGK1 kinase inhibitor SI113 blocks tumor progression in vitro and in vivo and synergizes with radiotherapy. Oncotarget 2015;6:37511-37525.

18 Salis O, Okuyucu A, Bedir A, Gor U, Kulcu C, Yenen E, Kilic N: Antimetastatic effect of fluvastatin on breast and hepatocellular carcinoma cells in relation to SGK1 and NDRG1 genes. Tumour Biol 2016;37:30173024.

19 Sommer EM, Dry H, Cross D, Guichard S, Davies BR, Alessi DR: Elevated SGK1 predicts resistance of breast cancer cells to Akt inhibitors. Biochem J 2013;452:499-508.

20 Liu G, Honisch S, Liu G, Schmidt S, Pantelakos S, Alkahtani S, Toulany M, Lang F, Stournaras C: Inhibition of SGK1 enhances mAR-induced apoptosis in MCF-7 breast cancer cells. Cancer Biol Ther 2015;16:52-59.

-21 Chatterjee S, Schmidt S, Pouli S, Honisch S, Alkahtani S, Stournaras C, Lang F: Membrane androgen receptor sensitive $\mathrm{Na}+\mathrm{H}+$ exchanger activity in prostate cancer cells. FEBS Lett 2014;588:1571-1579.

-22 Srivastava M, Leighton X, Starr J, Eidelman O, Pollard HB: Diverse effects of ANXA7 and p53 on LNCaP prostate cancer cells are associated with regulation of SGK1 transcription and phosphorylation of the SGK1 target FOXO3A. Biomed Res Int 2014;2014:193635.

23 Simon P, Schneck M, Hochstetter T, Koutsouki E, Mittelbronn M, Merseburger A, Weigert C, Niess A, Lang F: Differential regulation of serum- and glucocorticoid-inducible kinase 1 (SGK1) splice variants based on alternative initiation of transcription. Cell Physiol Biochem 2007;20:715-728.

24 Weiler M, Blaes J, Pusch S, Sahm F, Czabanka M, Luger S, Bunse L, Solecki G, Eichwald V, Jugold M, Hodecker S, Osswald M, Meisner C, Hielscher T, Rubmann P, Pfenning PN, Ronellenfitsch M, Kempf T, Schnolzer M, Abdollahi A, Lang F, Bendszus M, von Deimling A, Winkler F, Weller M, Vajkoczy P, Platten M, Wick W: mTOR target NDRG1 confers MGMT-dependent resistance to alkylating chemotherapy. Proc Natl Acad Sci U S A 2014;111:409-414. 


\section{Cellular Physiology Cell Physiol Biochem 2017;43:1301-1308 and Biochemistry Published \begin{tabular}{l|l} 
DOI: 10.1159/000481842 & $\begin{array}{l}\text { C } 2017 \text { The Author(s). Published by S. Karger AG, Basel } \\
\text { www.karger.com/cpb }\end{array}$ \\
\hline
\end{tabular}}

Schmid et al.: SGK1 and the Survival of Rhabdomyosarcoma Cells

25 Talarico C, Dattilo V, D’Antona L, Barone A, Amodio N, Belviso S, Musumeci F, Abbruzzese C, Bianco C, Trapasso F, Schenone S, Alcaro S, Ortuso F, Florio T, Paggi MG, Perrotti N, Amato R: SI113, a SGK1 inhibitor, potentiates the effects of radiotherapy, modulates the response to oxidative stress and induces cytotoxic autophagy in human glioblastoma multiforme cells. Oncotarget 2016;7:15868-15884.

-26 Xiaobo Y, Qiang L, Xiong Q, Zheng R, Jianhua Z, Zhifeng L, Yijiang S, Zheng J: Serum and glucocorticoid kinase 1 promoted the growth and migration of non-small cell lung cancer cells. Gene 2016;576:339-346.

27 Beauchamp RL, James MF, DeSouza PA, Wagh V, Zhao WN, Jordan JT, Stemmer-Rachamimov A, Plotkin SR, Gusella JF, Haggarty SJ, Ramesh V: A high-throughput kinome screen reveals serum/glucocorticoidregulated kinase 1 as a therapeutic target for NF2-deficient meningiomas. Oncotarget 2015;6:1698116997.

28 Kawka J, Sturm D, Pleier S, Pfister S, Marciniak-Czochra A: Revealing the role of SGK1 in the dynamics of medulloblastoma using a mathematical model. J Theor Biol 2014;354:105-112.

29 Moniz LS, Vanhaesebroeck B: AKT-ing out: SGK kinases come to the fore. Biochem J 2013;452:e11-13.

30 Amato R, Menniti M, Agosti V, Boito R, Costa N, Bond HM, Barbieri V, Tagliaferri P, Venuta S, Perrotti N: IL-2 signals through Sgk1 and inhibits proliferation and apoptosis in kidney cancer cells. J Mol Med (Berl) 2007;85:707-721.

-31 Lang F, Bohmer C, Palmada M, Seebohm G, Strutz-Seebohm N, Vallon V: (Patho)physiological significance of the serum- and glucocorticoid-inducible kinase isoforms. Physiol Rev 2006;86:1151-1178.

-32 Ackermann TF, Boini KM, Beier N, Scholz W, Fuchss T, Lang F: EMD638683, a novel SGK inhibitor with antihypertensive potency. Cell Physiol Biochem 2011;28:137-146.

33 Yu W, Honisch S, Schmidt S, Yan J, Schmid E, Alkahtani S, AlKahtane AA, Alarifi S, Stournaras C, Lang F: Chorein Sensitive Orai1 Expression and Store Operated Ca2+ Entry in Rhabdomyosarcoma Cells. Cell Physiol Biochem 2016;40:1141-1152.

34 Salker MS, Hosseinzadeh Z, Alowayed N, Zeng N, Umbach AT, Webster Z, Singh Y, Brosens JJ, Lang F: LEFTYA Activates the Epithelial $\mathrm{Na}+$ Channel (ENaC) in Endometrial Cells via Serum and Glucocorticoid Inducible Kinase SGK1. Cell Physiol Biochem 2016;39:1295-1306.

-35 Armeanu-Ebinger S, Bonin M, Habig K, Poremba C, Koscielniak E, Godzinski J, Warmann SW, Fuchs J, Seitz G: Differential expression of invasion promoting genes in childhood rhabdomyosarcoma. Int J Oncol 2011;38:993-1000.

-36 Herrmann D, Seitz G, Warmann SW, Bonin M, Fuchs J, Armeanu-Ebinger S: Cetuximab promotes immunotoxicity against rhabdomyosarcoma in vitro. J Immunother 2010;33:279-286.

-37 Mosmann T: Rapid colorimetric assay for cellular growth and survival: application to proliferation and cytotoxicity assays. J Immunol Methods 1983;65:55-63.

-38 Schmid E, Stagno MJ, Yan J, Stournaras C, Lang F, Fuchs J, Seitz G: Store-operated Ca(2+) entry in rhabdomyosarcoma cells. Biochem Biophys Res Commun 2016;477:129-136.

39 Sakoda H, Gotoh Y, Katagiri H, Kurokawa M, Ono H, Onishi Y, Anai M, Ogihara T, Fujishiro M, Fukushima Y, Abe M, Shojima N, Kikuchi M, Oka Y, Hirai H, Asano T: Differing roles of Akt and serum- and glucocorticoid-regulated kinase in glucose metabolism, DNA synthesis, and oncogenic activity. J Biol Chem 2003;278:25802-25807.

40 McCaig C, Potter L, Abramczyk 0, Murray JT: Phosphorylation of NDRG1 is temporally and spatially controlled during the cell cycle. Biochem Biophys Res Commun 2011;411:227-234.

41 Murakami Y, Hosoi F, Izumi H, Maruyama Y, Ureshino H, Watari K, Kohno K, Kuwano M, Ono M: Identification of sites subjected to serine/threonine phosphorylation by SGK1 affecting N-myc downstream-regulated gene 1 (NDRG1)/Cap43-dependent suppression of angiogenic CXC chemokine expression in human pancreatic cancer cells. Biochem Biophys Res Commun 2010;396:376-381.

42 Dehner M, Hadjihannas M, Weiske J, Huber 0, Behrens J: Wnt signaling inhibits Forkhead box 03a-induced transcription and apoptosis through up-regulation of serum- and glucocorticoid-inducible kinase 1. J Biol Chem 2008;283:19201-19210.

43 Huang H, Tindall DJ: Dynamic FoxO transcription factors. J Cell Sci 2007;120:2479-2487.

44 Zhang L, Cui R, Cheng X, Du J: Antiapoptotic effect of serum and glucocorticoid-inducible protein kinase is mediated by novel mechanism activating I\{kappa\}B kinase. Cancer Res 2005;65:457-464.

45 Wang K, Gu S, Nasir O, Foller M, Ackermann TF, Klingel K, Kandolf R, Kuhl D, Stournaras C, Lang F: SGK1dependent intestinal tumor growth in APC-deficient mice. Cell Physiol Biochem 2010;25:271-278.

$\checkmark 46$ Dattilo V, D’Antona L, Talarico C, Capula M, Catalogna G, Iuliano R, Schenone S, Roperto S, Bianco C, Perrotti N, Amato R: SGK1 affects RAN/RANBP1/RANGAP1 via SP1 to play a critical role in pre-miRNA nuclear export: a new route of epigenomic regulation. Sci Rep 2017;7:45361. 